\title{
PRECURSORS OF THE BOTANICAL EXPLORATION OF SOUTH AMERICA. WILHELM PISO (1611-1678) AND GEORG MARCGRAVE (1610-1644)
}

\author{
Carlos Ossenbach
}

\author{
Orquideario 25 de Mayo, San José, Costa Rica • caossenb@racsa.co.cr
}

\begin{abstract}
The Dutch colonization of northeastern Brazil from 1630 to 1654 is described, with emphasis on the years 1636-1644, when the colony was under the administration of Johan-Maurits Prince of NassauSiegen (1604-1679). During his rule, the Company sent the geographer and astronomer Georg Marcgrave (1610-1644) and the physician Willem Piso (1611-1644) to Recife. Both explored northern Brazil and made rich botanical and zoological collections, which were published in Amsterdam in 1648, after Pisos's return, under the title Historia naturalis Brasiliae; a second edition followed in 1658. In this work Piso mentions for the first time the orchid Vanilla in its current spelling. Both Piso and Marcgrave collected and illustrated Catasetum maculatum L.C.R., whilst a third orchid species, Trigonidium acuminatum Batem., can be found in Marcgrave's herbarium.
\end{abstract}

Key words: Brazil, Catasetum, Herbaria, Marcgrave, Nassau-Siegen, Piso, Vanilla

The Dutch colonization of Brazil 1830-1854. The Netherlands had long been part of the Spanish Empire until, during the Eighty Years' War (1568-1648), the Dutch established the Republic of the Seven United Netherlands (The Dutch Republic). The Dutch involvement in Brazil began in 1594, when Phillip II of Spain granted a special permit for a fleet of twenty Dutch ships to sail to the Portuguese colony once a year - Portugal being in a dynastic union with Spain from 1580 to 1640 . In 1609 Spain and the Dutch Republic signed a Twelve Years' Truce, in which the Dutch were allowed to trade with Portuguese settlements in Brazil, Portugal's small size and small population meant that it needed foreign participation in the colonization and the commerce of its overseas empire; the Dutch provided such mutually beneficial collaboration. As part of the truce the Dutch also agreed to delay the creation of a West India Company -- a counterpart to the already existing Dutch East India Company -- thus explicitly renouncing trade with the Spanish colonies in America.

By the end of the truce in 1621, the Dutch Republic had vastly expanded its trade networks, gaining over half of the cargo trade between Brazil and Europe. As a result, from three sugar refineries in the Northern Netherlands in 1595 the industry had grown to 29 by 1622. When the peace treaty expired, the Dutch West India Company was immediately created. Through the new company the Dutch now started to interfere in the Spanish and Portuguese possessions in America.
In December 1623, as part of the Groot Desseyn (grand design), Admiral Jacob Willekens led an expedition comprising 26 ships and 3,300 men of the Dutch West India Company (WIC) to Salvador, then the capital of Brazil and the center of Brazil's sugarcane production. They arrived there on May $8^{\text {th }}$ 1624 and soon forced the surrender of the Portuguese Governor, Diogo Tristão de Mendonça Furtado. However, by April 30th 1625 and with help from Spain, the Portuguese recaptured the city. During the next three decades the city was to play a critical role as a base of the Portuguese struggle against the Dutch for the control of Brazil.

Part of the plan was also to conquer the main Portuguese fort and slave station on the coast of Angola, São Paulo de Loanda (Luanda). In this way the company would control both the lucrative sugar plantations in Brazil and the Atlantic slave trade. Control of the trade itself was necessary because of the high mortality rate in the plantations' harsh conditions and from tropical diseases such as malaria.

In 1628 the seizure of a Spanish silver convoy by Piet Heyn in Matanzas Bay (Cuba) provided the Dutch WIC with the funds for another attempt to conquer Brazil. this time through Pernambuco. In the summer of 1629 the Dutch finally landed, gaining control of Olinda and Recife (the capital of Pernambuco) by February 16th 1630. By 1634 the Dutch controlled the coastline from the Rio Grande 


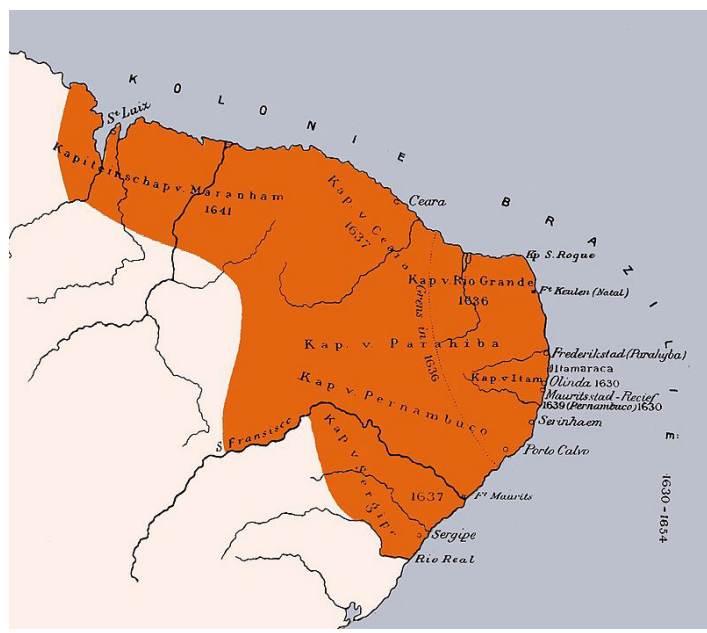

Figure 1. Map of Nieuw Holland (New Holland = Dutch Brazil), around 1641.

do Norte to Pernambuco's Cabo de Santo Agostinho. They still maintained control of the seas as well. By 1635 many Portuguese settlers were choosing Dutchoccupied land over Portuguese-controlled land as the Dutch offered freedom of worship and security of property. In the same year the Dutch conquered three Portuguese towns: Porto Calvo, Arraial do Bom Jesus, and Fort Nazaré on Cabo de Santo Agostinho. These strongholds expanded the Dutch sugar lands which led to an increase in profitability (Fig.1).

\section{Dutch Brazil under Johan Maurits van Nassau-}

Siegen. In 1636 the Dutch West Indian Company gave control of its Brazilian possessions, now called "Nieuw Holland," to Count, later Prince, Johan Maurits van Nassau-Siegen (1604-1679) (Fig. 2), the great-nephew of William the Silent (William I, Prince of Orange, 1533-1584, leader of the Dutch revolt against the Spaniards). He landed at Recife in January of 1637.

Within the year, he had conquered the Brazilian province of Ceara and sent a fleet to capture the West African trading post of Elmina Castle, which became the capital of the Dutch Gold Coast. In 1641 the Dutch captured the province of Maranhão, meaning that Dutch control now extended across the entire north and the coastline between the Amazon and Sao Francisco Rivers (Fig. 3). His exploits meant that in later years Maurits was often called the Brazilian.

Under Maurits' rule, the colony thrived. He commissioned Golden Age painters, such as Albert

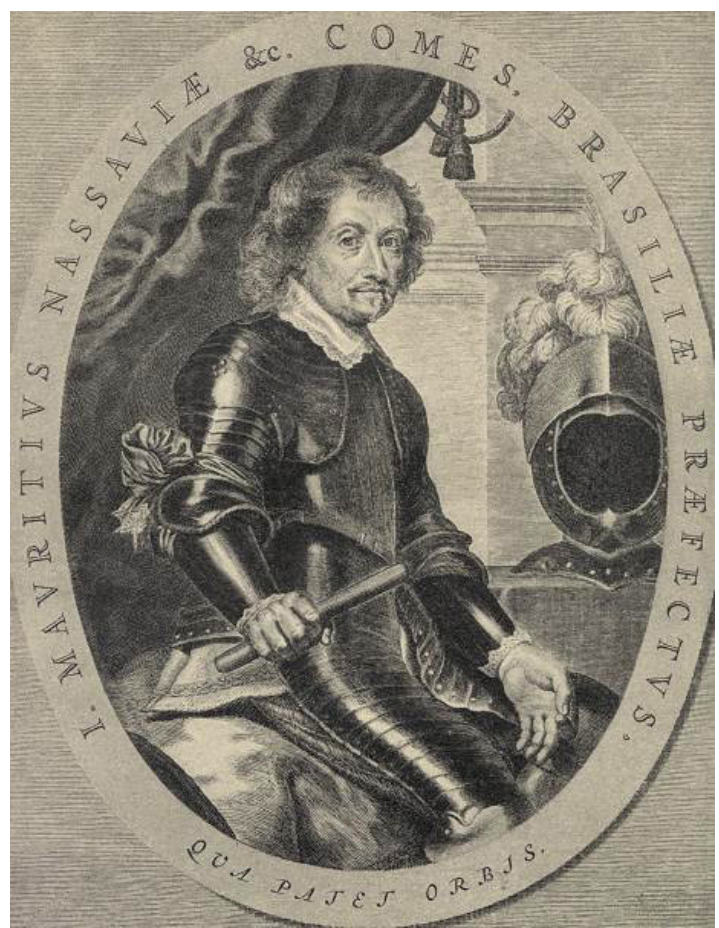

FiguRE 2. Johan-Maurits of Nassau-Siegen (104-1679). Unknown artist.

Eckhout (1610-1655) and Frans Post (1680) (Fig. 4), to depict Brazil's richness, resulting in works showing different races, landscapes, and still lifes. On the island of António Vaz, he founded the town of Mauritsstad (also known as Mauricia), named after himself, where he created an astronomical observatory and a meteorological station, the first such created by Europeans in the Americas. In 1643 he equipped the expedition of Hendrik Brouwer, which unsuccessfully attempted to establish an outpost in southern Chile. In 1644, following the cession of hostilities, the WIC recalled him to Europe in an attempt to curb military expenditure.

Maurits also sought to explore the country's natural history and geography. To this end he sent for the physician Willem Piso (1611-1668) (Fig.5), the geographer and astronomer Georg Marcgrave (16101644) and a student of medicine and mathematics, H. Cralitz (who unfortunately succumbed to tropical disease, dying within 12 months of his arrival).

Willem Piso had finished his studies in Caen in 1633 and settled in Amsterdam as a doctor before leaving for Brazil. Georg Marcgrave was born in Liebstadt near 


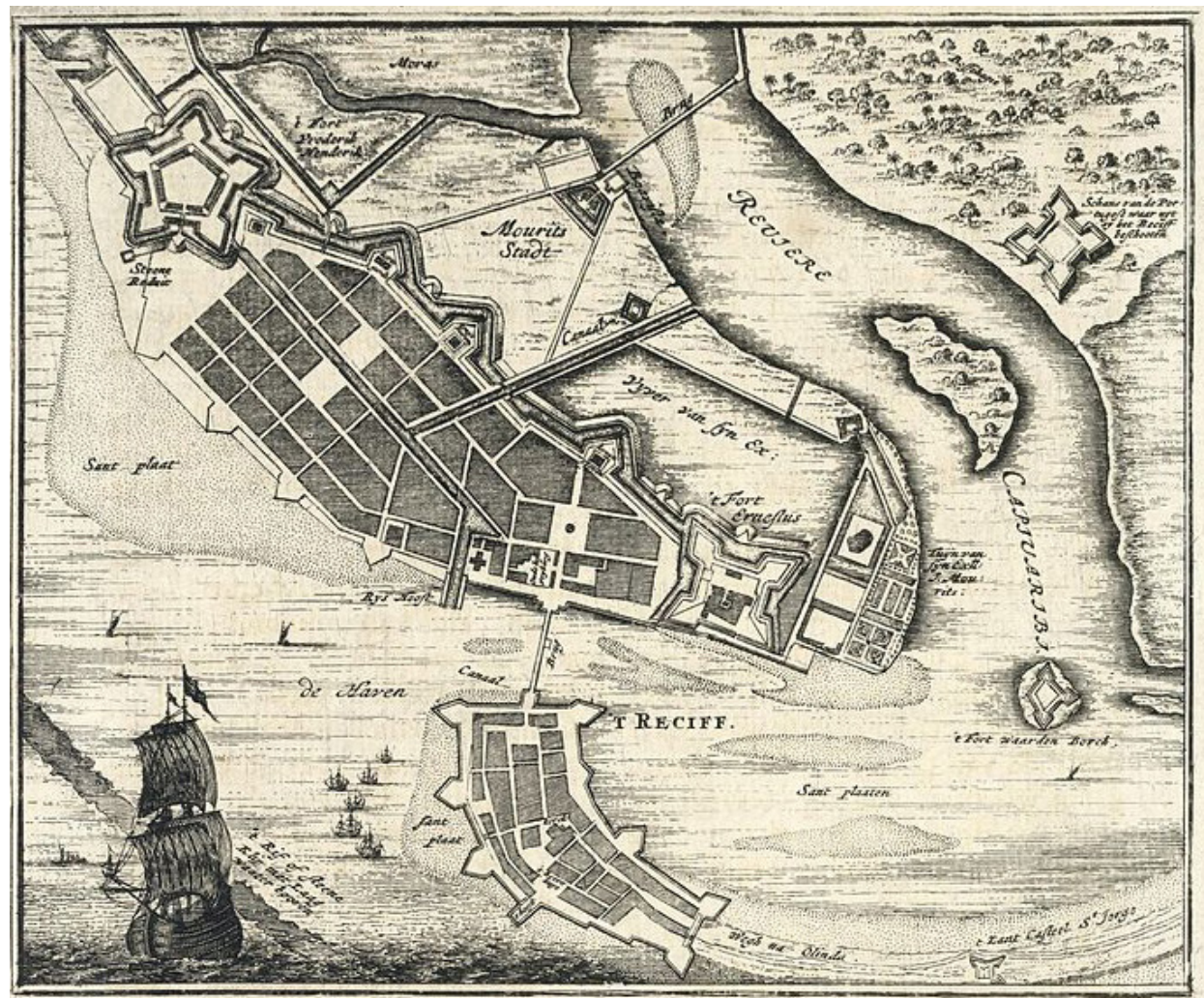

Figure 3. Map of Recife and Mauritsstad. By Georg Marcgrave.

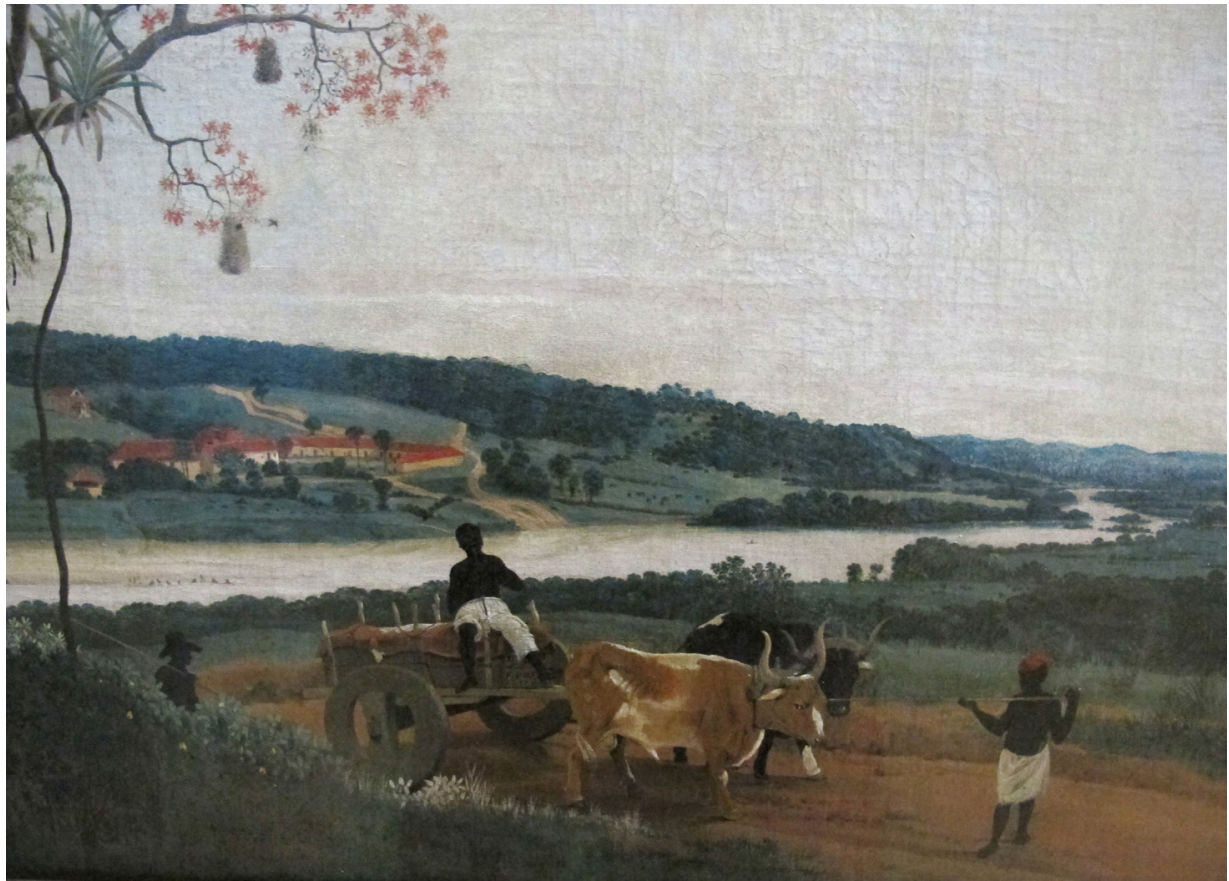

Figure 4. Brazilian landscape with oxcart by Frans Post (1838). 


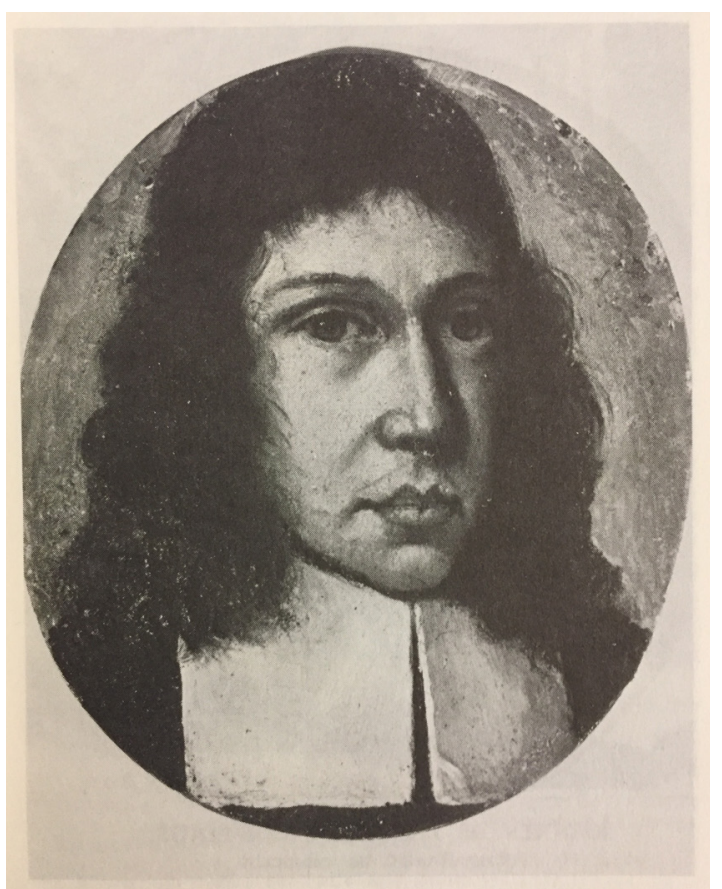

Figure 5. Willem Piso (1611-1678).

Dresden and studied astronomy, botany, mathematics and medicine at German and Swiss universities before moving to Leiden, Holland, in 1636. Once in Recife Marcgrave won favour with the Count, who let him work at his observatory. Both scientists worked as physicians to the Dutch forces in the region, Piso recommending the consumption of fresh fish, vegetables, and fruits after discovering that soldiers and seamen suffered from physical problems resulting from malnutrition. Marcgrave travelled extensively with Piso, collecting animals and plants over a wide area. However, he was eventually stricken with a lethal fever. While preparing to sail for home in 1644, Marcgrave was unexpectedly called upon to travel to Angola, where, on arrival, he died from the illness.

The Count and Willem Piso thus returned to Holland without Marcgrave or Cralitz, but laden with considerable collections of specimens and the very confusing notes of Marcgrave, who had written his natural history findings in a cipher, purportedly to prevent Piso for claiming credit for the work. Marcgrave, with great foresight, was indeed attempting to foil any act of plagiarism on the part of the physician. Willem Piso's contributions to the first edition of Historia Naturalis Brasiliae (1648) (Fig. 6), in twelve volumes, were published under the heading De medicine Brasiliense. The eight volumes on botany and zoology were compiled from the material authored by Marcgrave, decoded and edited by Johannes de Laet (1593-1649), one of the directors of the Dutch West India Company.

Ten years later, a second edition of this work appeared under the title De Indiae Utrusque re naturali et medica (Fig. 7), in which Piso carelessly made his own treatment of Marcgrave's work, omitting most of Marcgrave's botanical descriptions and without mentioning Johannes de Laet. For this he was severely criticized by, among others, Carolus Linnaeus. This second edition was complemented with a chapter written by the Dutch physician Jakobus Bontii (Jacob Bontius) (1592-1631) on medicinal plants from Batavia (Dutch East Indies).

This work must be considered as the earliest ethnobotanical study of the Brazilian flora and one of the first treatises on tropical plants and human diseases. It is complemented by a herbarium with 177 specimens collected by Marcgrave, and has been kept in the Botanical Museum of Copenhagen since 1653.

In the spring of 1646 the Dutch sent a relief expedition to Recife, temporarily forestalling the fall of the city. Back in Europe, the collapse of Dutch Brazil accelerated Dutch efforts to end the Eighty Years' War, its longstanding conflict with Spain. In August 1647 Dutch representatives acquiesced to the Peace of Munster ending the war with Spain. A second, larger relief expedition then set out to reconquer Brazil.

In Brazil the Dutch had already abandoned Itamaracá on December $13^{\text {th }} 1647$. The new expeditionary force arrived late at Recife, with many of its soldiers either dead or mutinous from lack of pay. On April 1648 the Portuguese routed this expeditionary force at the First Battle of Guararapes, fought outside Recife. On February 1649 the Portuguese defeated the Dutch again at the Second Battle of Guararapes. The Dutch finally lost control of Recife on January 28th 1654, leaving to the Portuguese their colony of Brazil and putting an end to Nieuw Holland (Fig. 8).

Meanwhile, the British, French, and Dutch Caribbean colonies had become major competitors to Brazilian sugar due to rising sugar prices in the 1630s and 1640s. After the Dutch evacuated Pernambuco, they brought their expertise and capital to the 


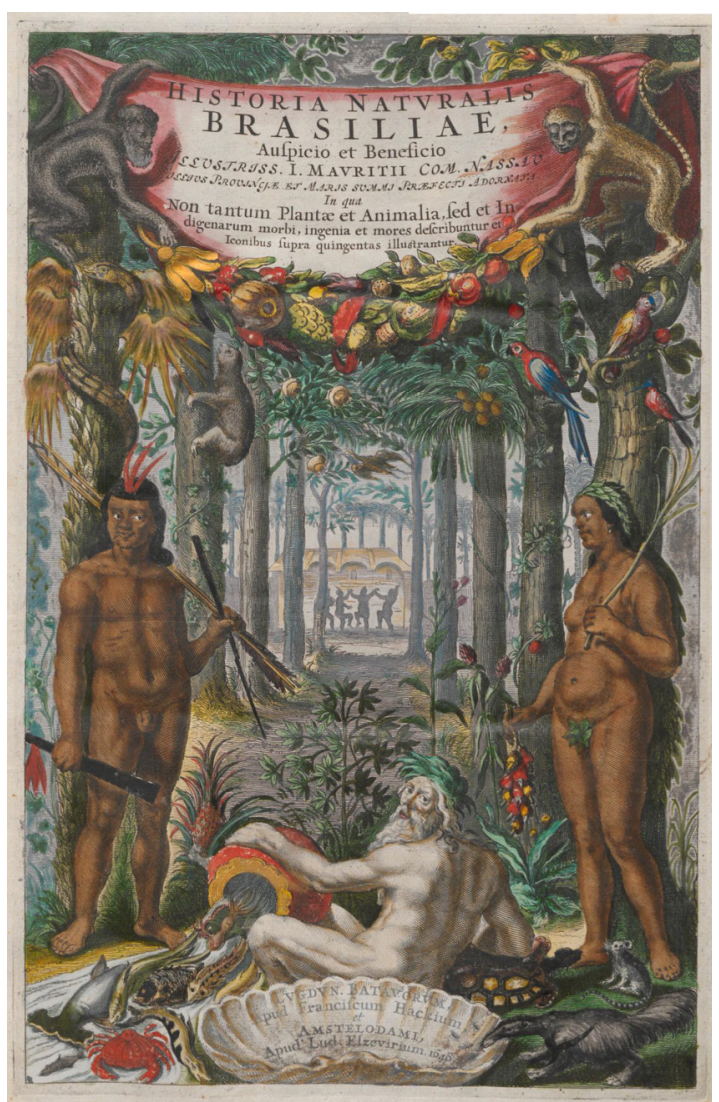

FIGURE 6. Frontispiece of Piso's first edition (1648).

Caribbean. In the $1630 \mathrm{~s}$, Brazil provided $80 \%$ of the sugar sold in London, while by 1690 it only provided $10 \%$. The Portuguese colony of Brazil did not recover economically until the discovery of gold in southern Brazil during the 18 th century.

Orchids in the works of Piso and Marcgrave. Willem Piso has gained a name among orchidologists for having been the first to use the term Vanilla in its present spelling. In the 1658 edition of his De Indiae Utriusque re naturali et medica (Piso, 1658: Mantissa Aromatica) he writes: [...] est herba Mexicanis 'Tlilxochitl' dicta, quam Francisc. Hernandez 'Araco Aromatico' comparat. [...] quas vulgus Hispanorum a vaginarum similitudine 'Vaynillas' appellat. (it is a herb which the Mexicans call 'Tlilxochitl', that compares to that called 'Araco Aromatico' by Francisco Hernandez [...] which common Spaniards because of its similitude with the vagina call 'Vaynillas') (Fig. 9).

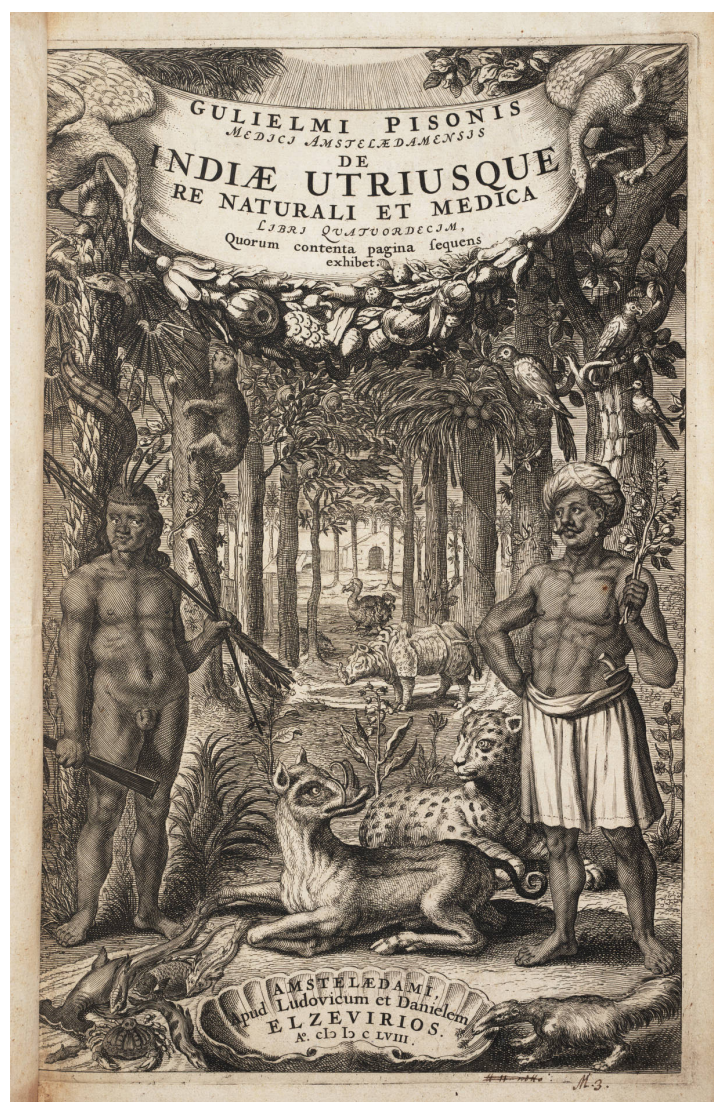

FIGURE 7. Frontispiece of Piso's second edition (1658).

The fact that Piso did not name Vaynilla in the first edition of his work ten years earlier was probably due to the fact that he only had access to the work of Francisco Hernández through the second edition of his Rerum Medicarum Novae Hispaniae Thesaurus, seu Plantarum, Animalium, Mineralium Mexicanarum Historia, published in 1651 by the Italian Accademia dei Lincei under the guidance of Francesco Stelluti. A first, very incomplete, edition had been published in 1615 by Francisco Ximenez, and is cited once by Marcgrave in the edition of Historia Naturalis Brasiliae of 1648; a further reduced edition was brought out in 1628 by the same Accademia dei Lincei. (Ossenbach 2009).

Another orchid is mentioned and illustrated in Piso's first edition of 1648 (Piso 1648) and named Tupaipi, aliis Urucatu, which Pickel (2008) has identified as Catasetum macrocarpum L.C.Rich. ex Kunth (Pickel 2008) (Fig. 10). The same plant, with an identical illustration but a different description can be found in 


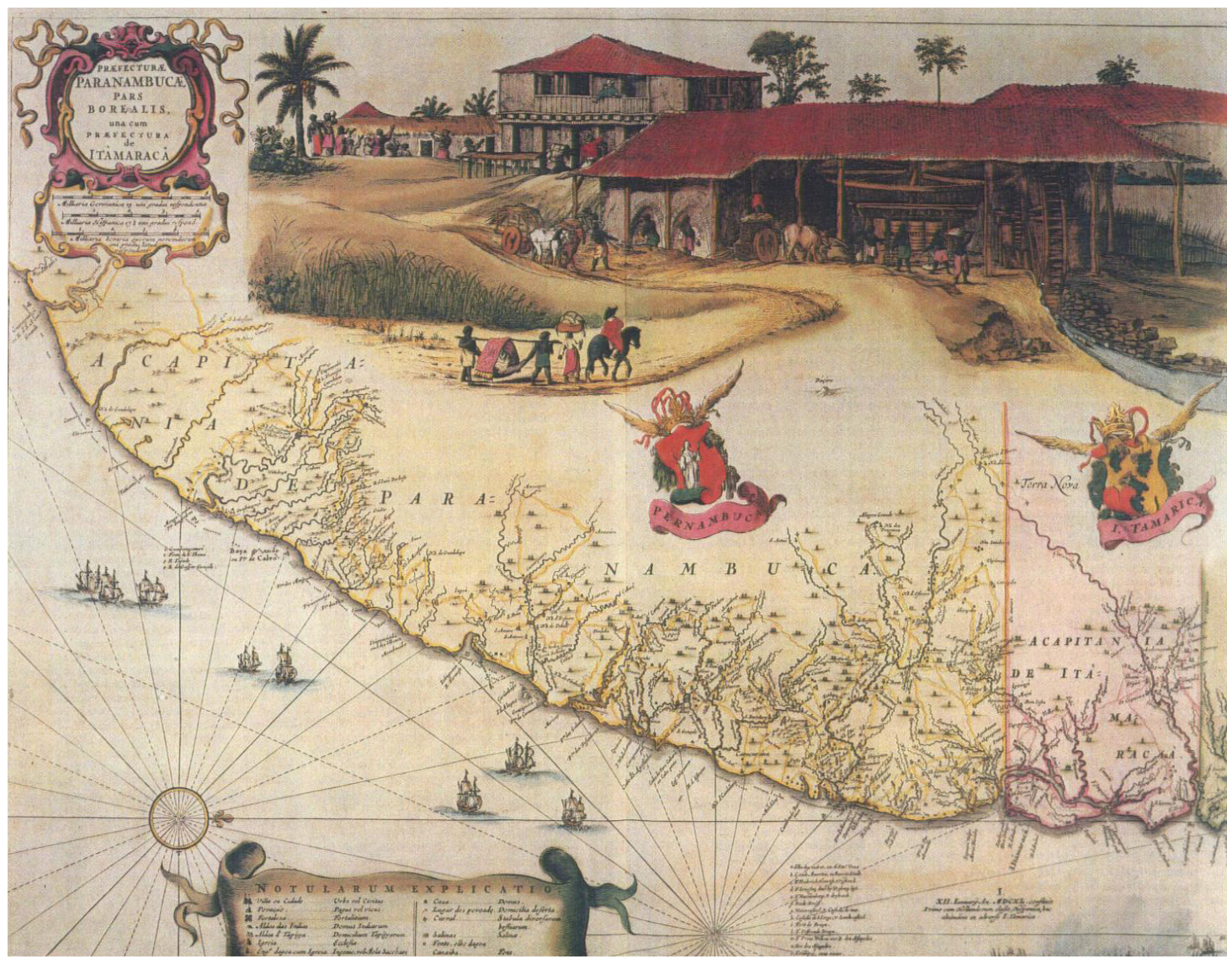

Figure 8. Map of the coast Pernambuco by Post and Marcgrave.

the same edition of 1648 , but in the volumes written by Marcgrave (Marcgrave 1648) (Fig. 11) where it was described by him as Urucatú Brasiliensum. Both names used by Piso and Marcgrave, Tupaipi and Urucatú, belong to the language of the Tupinambá tribe of the Amazonas region (Alcántara Rodríguez
2015: Appendix 1). According to Hoehne (1949) tupaipi or tupaypy means 'of divine origin'.

A third orchid specimen described and illustrated by Marcgrave in the 1648 edition has been identified as Trigonidium acuminatum Bateman (Fig. 12).

Georg Marcgrave's herbarium can be found today

Quarta inter calidas cft lucrba Mexicanıs ratcxochttl dicta, quam rrancifc. Hernandez Araco Aromatico comparat. Volubilis herba Hederr more arbores confcendens. Foliis eft unciis undecim longis, fex latis, figur a Plantaginis, fed pinguioribus, faturate viridibus, fingulis exutraque parte caulis alternatim exorientibus, floribus nigricantibus. Siliquis fex unçias longis, anguftis, \& pene teretibus,nigris, olentibus Mufcum aut Balfamum indigenam, quas vulgus Hifpanorum à vaginarum fimilitudine Vaynillas appcllat. $\mathrm{H} x$ ad tertium ordinem habentur calidx, addique folitx potioni Chocolate, ob finvem non folum odorem, \& faporem; fed quod urinas $\&$ menftrua moveant, cerebium confortent, flatus difcutiant, humor efque crudos concoquant, \& attenuent. Icon exftat in opere Fr. Hernandez fol. 38.

Figure 9. Piso's description of Vaynilla. Page 200 (Appendix: Mantisssa Aromatica) of his 1658 edition of De Indiae

Utrusque re naturali et medica. 


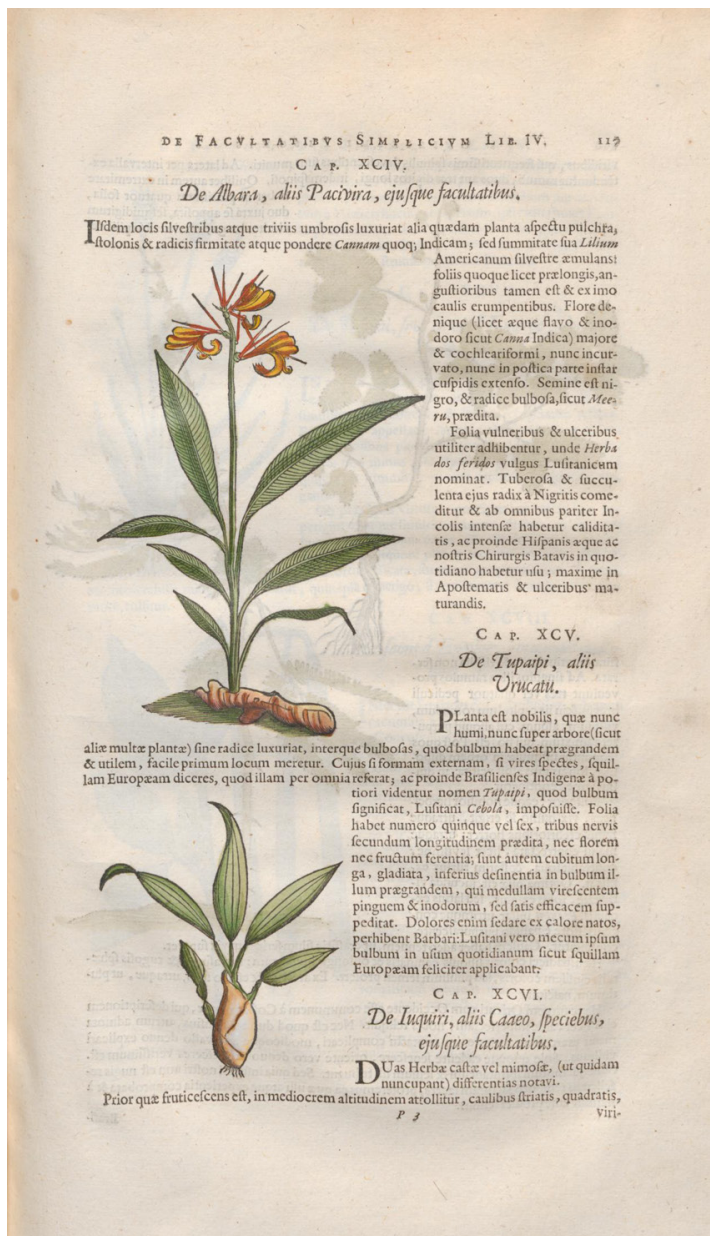

Figure 10. Piso's description and illustration of Tupaipi, aliis urucatú in page (P)117 of his 1648 edition of Historia Naturalis Brasiliae.

at the Natural History Museum of the University of Copenhagen, Denmark. A clue to its history is given in the letters of Ole Worm (1588-1644), a professor of medicine at the University of Copenhagen, who had made the acquaintance of Jan de Laet, the editor of the Historia Naturalis Brasiliae of Piso and Marcgrave. From this correspondence it appears that Worm received duplicates of minerals, wood samples and fruits from Marcgrave's collections. After de Laet's death in 1649, Worm's eldest son, Willum, went to study to Leiden in 1653. Soon after his arrival he bought, on behalf of his father, Marcgrave's herbarium, which was sent to Copenhagen, where it arrived in October of the same year. Ole Worm died in 1654 and in 1655 his collections, including Marcgrave's herbarium, were

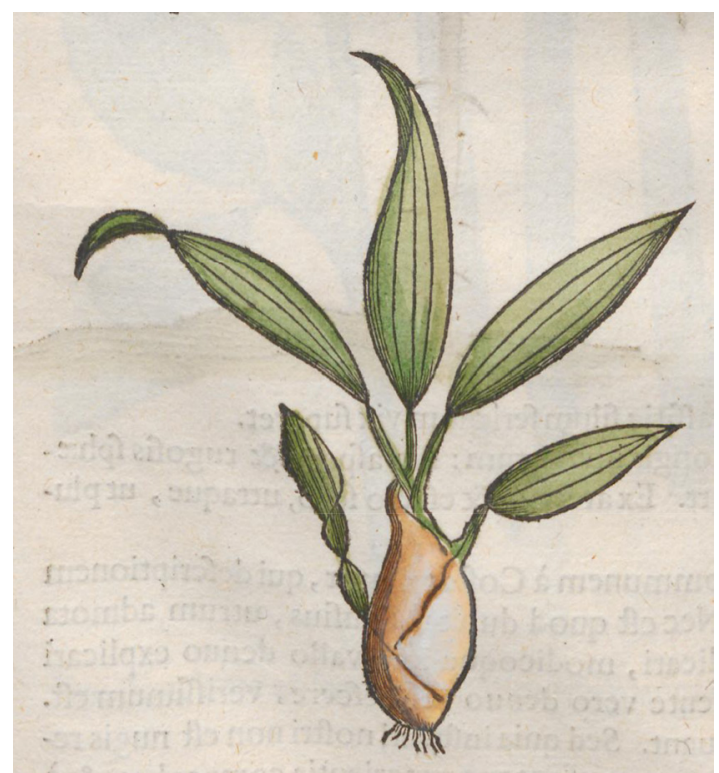

Figure 11. Marcgrave's description and illustration of Urucatú brasiliensibus in page (M) 35 of his 1648 edition of Historia Naturalis Brasiliae.

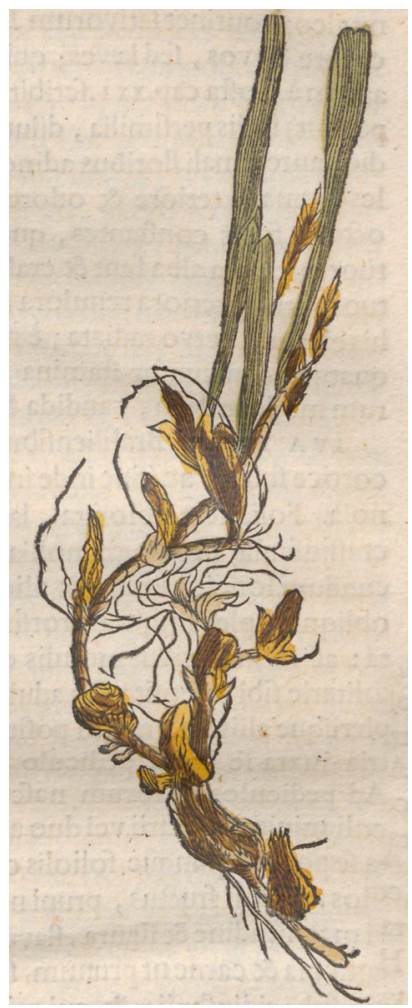

FIgURE 12. Marcgrave's illustration of Trigonidium acuminatum in page (M)107 of his 1648 edition of Historia Naturalis Brasiliae. 


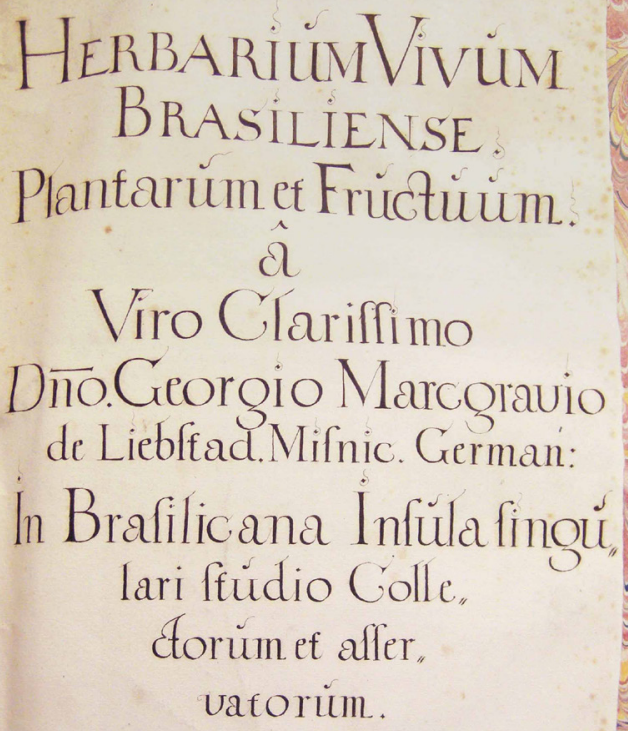

FiguRE 13. Title page of Marcgrave's herbarium, courtesy and reproduced with permission of the Natural History Museum of Denmark.

sold by the family to King Frederik III, after whose death in 1670 the collections were passed on to the Botanical Museum (Andrade-Lima et al. 1977).

The bound herbarium (Fig. 13) comprises 173 sheets with 177 plant collections. Four of these sheets contain mixed collections; for example, page number 18 (Fig. 14) which presents a specimen of Zollernia latifolia together with the epiphytic orchid Trigonidium acuminatum Bateman. The latter specimen can be recognized as the one illustrated in Marcgrave (1648). It is in all probability historically the first specimen of Orchidaceae ever prepared from tropical America.

\section{Marcgrave's herbarium in a historical perspective.}

That Marcgrave's herbarium holds in all probability the first dried specimens of plants from tropical America is based on strong evidence. Let us remember that the end of the $16^{\text {th }}$ and the beginning of the $17^{\text {th }}$ centuries, the time which saw the rise of the Scientific Revolution, was the time when, slowly, the pages of the herbaria, the 'hortus siccus' (Latin $=$ 'the dry garden'), even more than those of the herbal, began to displace the garden as the principal instrument of botanical research. Herbaria could easily contain many thousand plants and could quickly be formed by those who travelled in distant lands. At the same time, those without land or talent for the cultivation of exotics might hoard them in their cabinets of curiosities. Like the 'pulvilli' (Italian for flower beds) of the botanic gardens, the drawers of the 'hortus siccus' offered a space for philosophical accumulation (Ossenbach 2017).

In the $16^{\text {th }}$ century botanical gardens were already helping to add to the knowledge of plants; the first were formed in Italy at Padua in 1545, Pisa in 1547, and Bologna in 1567. Soon similar collections of living plants were made in northern Europe: in 1577 at Leiden and in 1593 at Heidelberg and Montpellier. The $16^{\text {th }}$ century Italian botanist Luca Ghini (1490?-1556), a Professor at the University of Bologna, is credited as the first person to press and preserve plants under sheets of paper and then to bind the specimens within a book. His two pupils, Aldrovandi and Cesalpino, are said to have formed the first herbaria in our sense of the word. One of the first collections of the kind, perhaps made as early as 1556 , was the herbarium formed by Carl Ratzenberger in Wittenberg. (Sachs 1890). Other herbaria followed, such as those of Jehan Girault in 1558 in Paris, and Felix Platter in Basel, who lived from 1536 to 1614. In various cities in Europe, more than twenty herbaria are preserved, which were formed, or at least begun, in the sixteenth century (Arber 1912).

In 1606 Adriaan van de Spiegel (1578-1625) published instructions on producing dried herbarium specimens in his Isagoges in Rem Herbarium. The oldest herbarium known from the 17th century (the oldest in Britain, today part of the Oxford University Herbarium), is the herbarium volume of Gregorio a Reggio. He was an industrious Capuchin monk who studied and collected plants in the region of Emilia, near Bologna (Marner 2006). This herbarium is labelled "Herbarium Diversarum Naturalium Gregorio a Reggio" (Fig. 15), and the collection is dated 1606, approximately 35 years before Marcgrave's herbarium. 


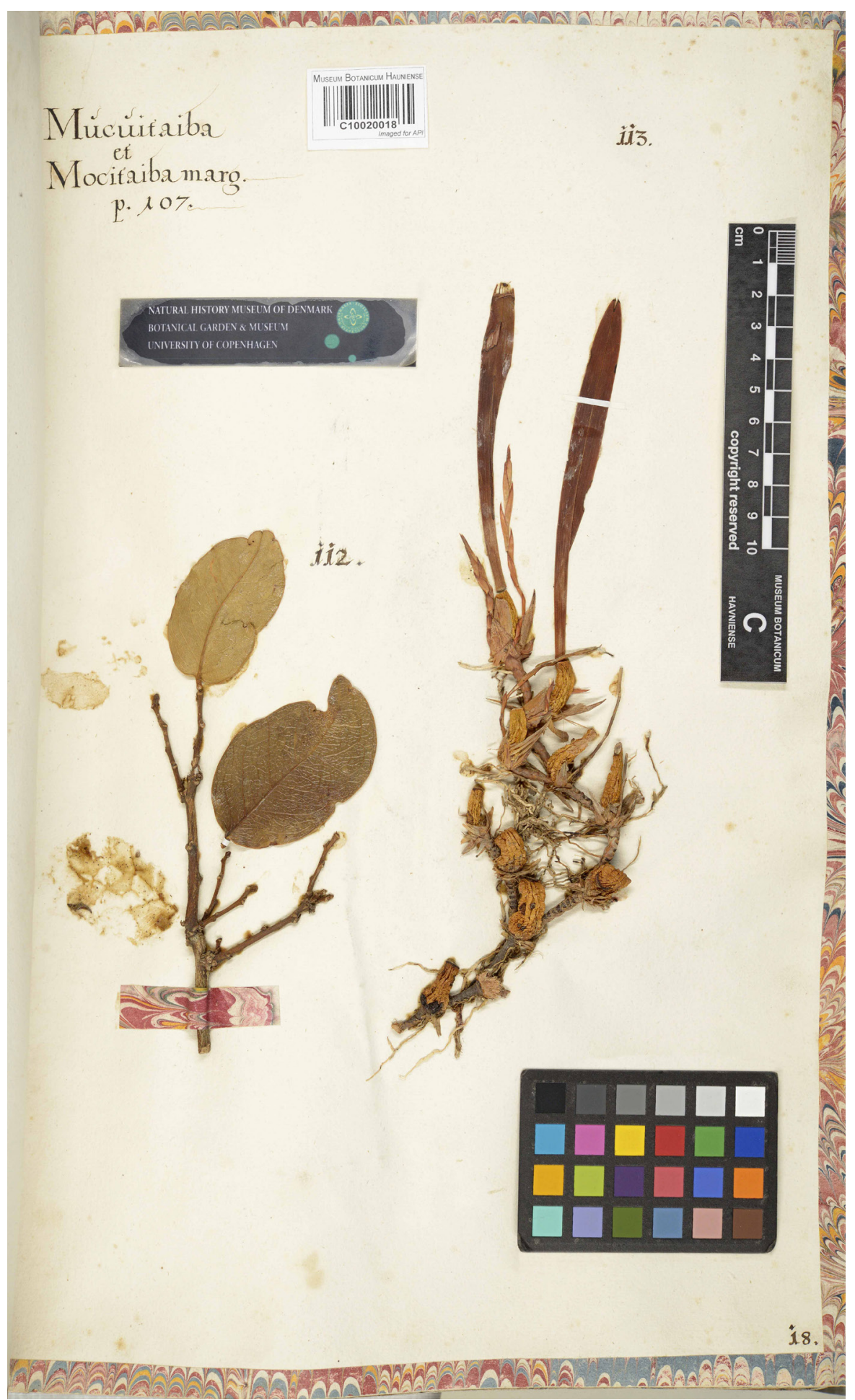

Figure 14. Page 18 of Marcgrave's herbarium. Courtesy and reproduced with permission of the Natural History Museum of Denmark. 


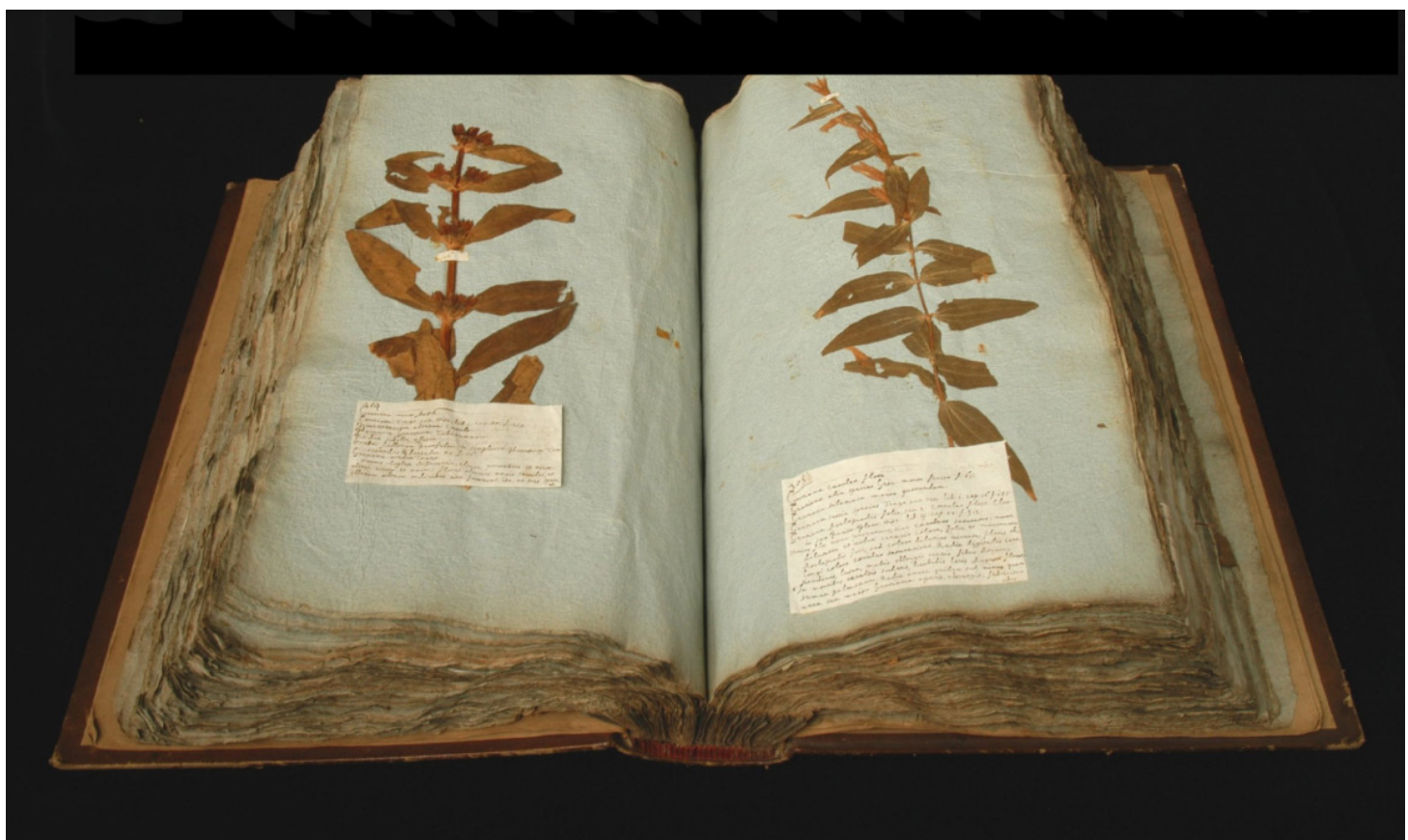

FIgURE 15. Book herbarium of Gregorio a Reggio.

If we additionally consider the difficulties of travelling in these years, and the fact that the Spanish and Portuguese posessions in America were jealously closed against all foreigners, then the chance of a tropical plant finding a way into a European herbarium in the late $16^{\text {th }}$ or early $17^{\text {th }}$ centuries was indeed very small, if not nil. Only the combination of a strong Dutch military force, able to break into those possessions, and a learned and enlightened Governor, willing to bring scientists and men of art across the Atlantic, made this botanical exploration and thus Marcgrave's herbarium possible.

It is surely no coincidence that the famous Accademia dei Lincei, from whose publications of the

\section{LITERATURE CITED}

Alcántara Rodríguez, M. (2015). Medicinal and other useful plants from Historia Naturalis Brasiliae (1648): Are they currently used in Brazil? Major Research Project. Utrecht University.

Andrade-Lima, D. de, Fox-Maule, A., Pedersen, T. M. \& Rahn, K. (1977). Marcgrave's Brazilian Herbarium Collected 1638-1644. Botanisk Tidsskrift, 71: 121-160.

Arber, A. (1912). Herbals: their origin and evolution. A chapter in the history of Botany, 1470-1670. Cambridge University Press. works by Francisco Hernández Piso and Marcgrave had drawn so much of their knowledge of American plants, was founded by Federico Cesi during the same period, in 1603.

Aknowledgements. Special thanks must be expressed to Professor Nina Rønsted and Dr. Olof Ryding from the Natural History Museum of Denmark, University of Copenhagen, for providing the images of Marcgrave's Herbarium. Also to Diego Bogarín, presently at the University of Leiden, the Netherlands, for information and reproductions of Piso's and Marcgrave's works. Thanks also to both reviewers, especially to one of the reviewers for his careful revision of the English text.

Hoehne, F. C. (1949). Iconografia de Orchidaceaes do Brasil. Secretaria de Agricultura. São Paulo, Brazil.

Marner, S. (2006). 400 years old! [A book herbarium from Italy]. Oxford Plant Systematics (8): 8-10.

Ossenbach, C. (2009). Orchids and orchidology in Central America: 500 years of history. Lankesteriana 9 (1-2): 1-268.

Ossenbach, C. (2017). An Encyclopaedic History of Orchids and Orchidology in the Antilles. Koeltz Botanical Books. Oberreifenberg, Germany. 
Pickel, B. J. (2008). Flora do Nordeste do Brasil segundo Piso e Marcgrave no século XVII. Argus Vasconcelos de Almeida (Ed.). Editora da Universidade Federal Rural de Pernambuco, Recife.

Piso, W. (1658). Indiae utriusque re naturali et medica. L. \& D. Elzevirios, Amsterdam.
Piso, W. \& Marcgrave, G. (1648). Historia naturalis Brasiliae. Hackium \& Elizevirium.

Sachs, J. von. (1890). History of Botany (1530-1860). Translated by Henry E. F. Garnsey. Clarendon Press, Oxford. 
